\title{
Coronary Arterial Involvement in Takayasu's Disease
}

\author{
Naoki Makino, M.D., Yasuhiko Orita, M.D., \\ Akira Takeshita, M.D., Motoomi Nakamura, M.D., \\ Kanji Matsui, M.D.,* and Koichi TokunagA, M.D.*
}

\section{Summary}

This report describes the findings in a young woman with Takayasu's disease, resulting in angina pectoris due to severe narrowing of the left coronary ostium. The patient underwent aortocoronary bypass surgery. The disappearance of angina, with reversal of positive findings on the treadmill exercise test, was noted postoperatively. Selective coronary angiography should be performed in patients with Takayasu's disease with a positive exercise test and symptoms of chest pain.

\section{Additional Indexing Words:}

Angina pectoris Aortocoronary bypass Treadmill exercise test

TAKAYASU'S disease is an arterial inflammatory disease of unknown etiology, which commonly affects the aorta, its large branches, and the pulmonary artery.1)-3) The disease has a worldwide distribution. ${ }^{4), 51}$ It predominantly affects young women and most often is first detected during the second or third decades of life. Symptoms referable to cardiac involvement range from congestive heart failure to angina pectoris. ${ }^{3), 6), 7)}$ Postmortem studies have revealed coronary occlusion and myocardial infarction in $9-10 \%$ of cases ${ }^{3,6)}$ of Takayasu's disease with angina. There is also documentation of 14 patients in whom stenotic lesions of the coronary arteries were angiographically demonstrated. ${ }^{8 / 19)}$ We recently treated a 23-year-old woman with Takayasu's disease with an associated angina pectoris. Coronary angiography revealed a left coronary ostial stenosis.

From the Research Institute of Angiocardiology and Cardiovascular Clinic and the Department of Cardiovascular Surgery, ${ }^{*}$ Kyushu University Medical School, Fukuoka.

Address for reprint: Naoki Makino, M.D., Research Institute of Angiocardiology and Cardiovascular Clinic, Kyushu University Medical School, 3-1-1 Maidashi, Higashi-ku, Fukuoka 812, Japan.

Received for publication November 17, 1981.

Manuscript revised December 28, 1981. 


\section{CASE Report}

A 23-year-old Japanese woman was hospitalized with angina pectoris of 5 months duration. Attacks were readily precipitated by minimal physical exertion, such as walking up a slope. She reported a right cervical pain of few months duration 3 years earlier which was associated with leucocytosis, increased erythrocyte sedimentation rate (ESR), and positive C-reactive protein (CRP). There was no family history of coronary artery disease. Physical examination on admission revealed a regular heart rate of $82 / \mathrm{min}$. The blood pressure was $124 / 70 \mathrm{mmHg}$, and there was no laterality or difference between the upper and lower extremities. Optic fundi were normal. The temporal arteries were easily palpable and not tender. There was no cardiac enlargement. The heart sounds were normal and there was a grade II systolic bruit at the right side of the neck. All peripheral pulses were palpable.

Laboratory studies revealed normal urinalysis, normal blood cell counts, blood urea nitrogen, serum creatinine, and serum lipid levels. Serum protein electrophoresis and thyroid function tests were normal. ESR was $17 \mathrm{~mm}$ in 1 hour. CRP was one plus positive. A serological test for syphilis and a test for rheumatoid factor, antinuclear antibody and lupus erythematosus prep-

A
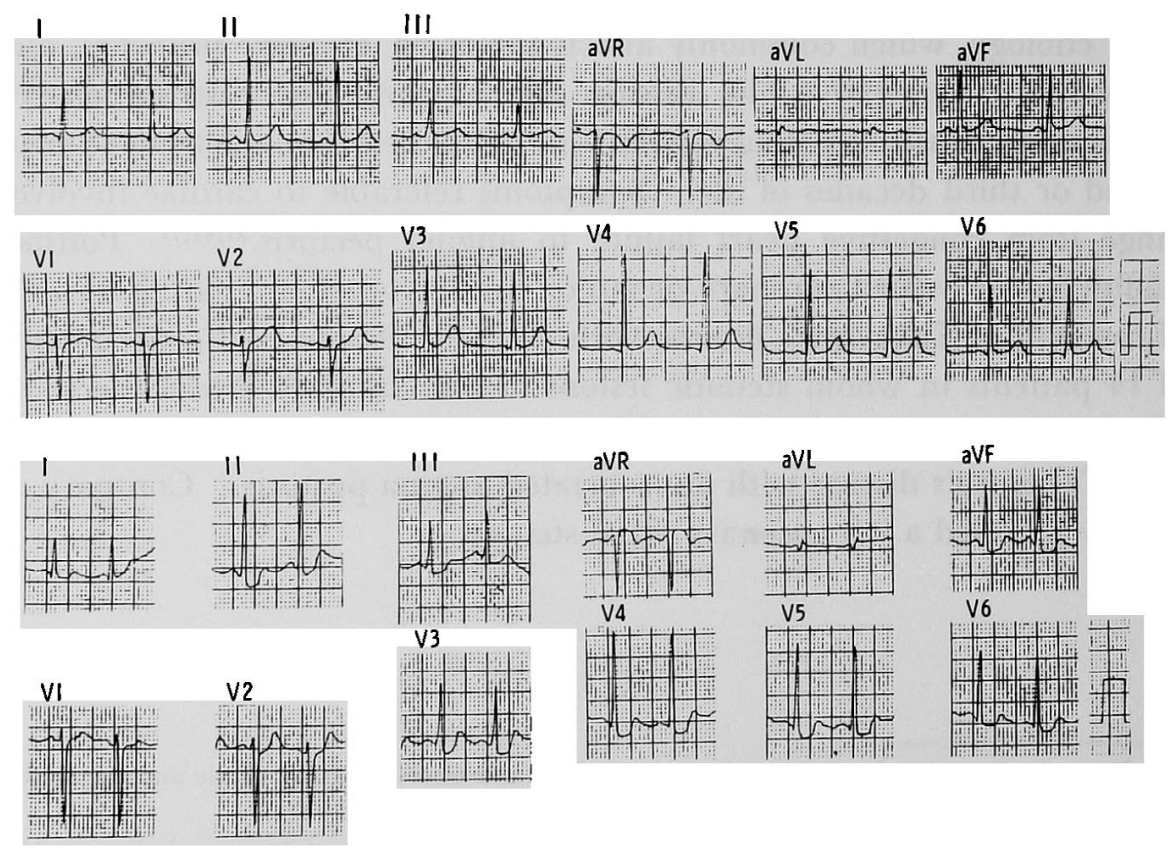

aVF

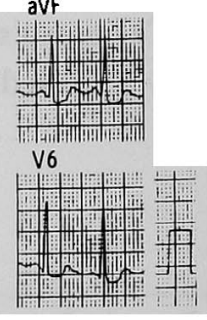

Fig. 1. A: electrocardiogram in the resting state is within normal limits. B: positive treadmill exercise electrocardiogram with $0.4 \mathrm{mV}$ ST segment depression in lead II, III, $\mathrm{aV}_{\mathrm{F}}$, and $\mathrm{V}_{3-B}$. 
arations were all negative. The resting electrocardiogram was within normal limits (Fig. 1A). A treadmill exercise test showed ST segment depression of $0.4 \mathrm{mV}$ in II, III, $\mathrm{aV}_{\mathrm{F}}$, and $\mathrm{V}_{3^{-6}}$ after exercising to the Bruce stage 2 (Fig. 1B), when she developed a typical chest pain of effort angina. At the end point

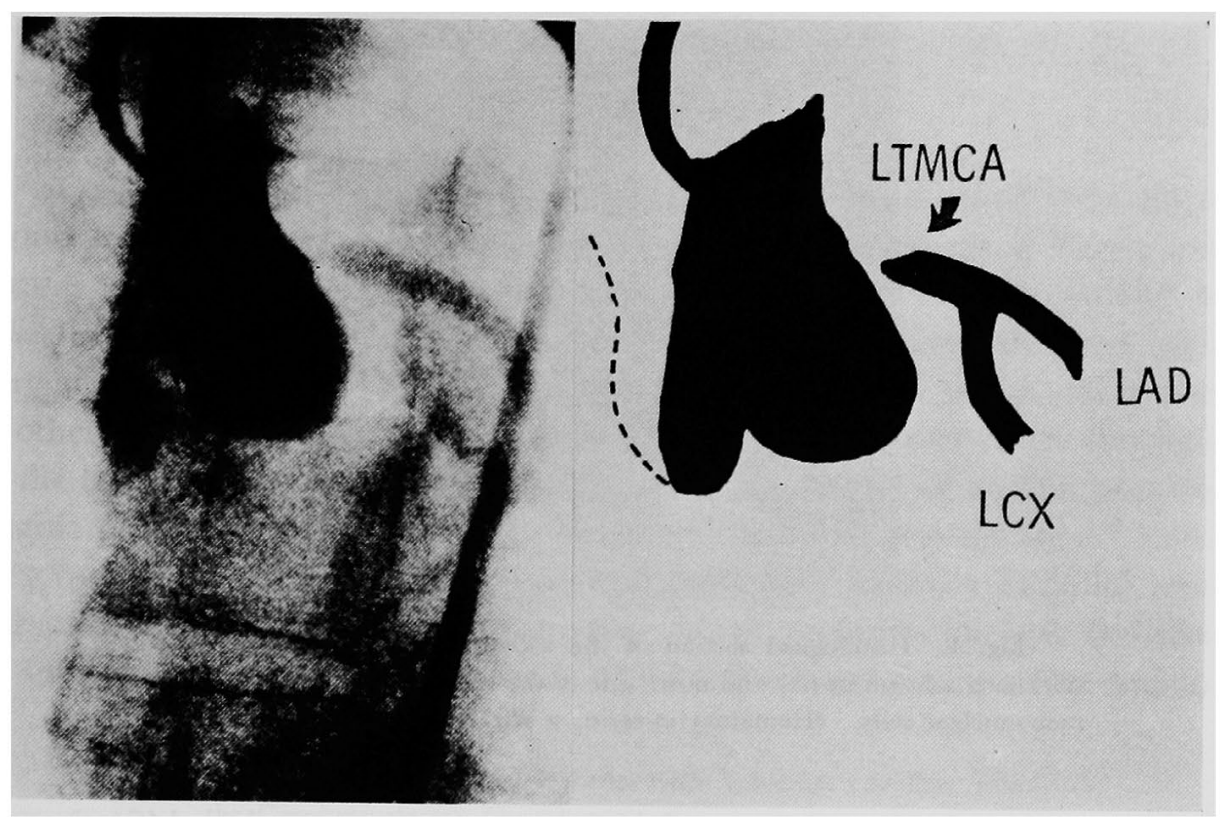

Fig. 2. Selective coronary angiogram. The left main coronary artery is almost completely occluded. LTMGA = left main coronary artery; LCX = left circumflex coronary artery; LAD = left anterior descending coronary artery.

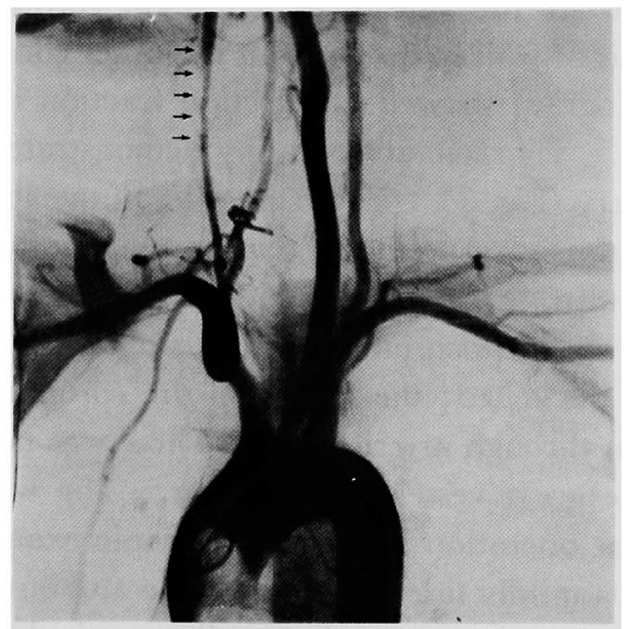

Fig. 3. Thoracic aortogram shows an irregularity and narrowing at the right carotid artery (arrows). 


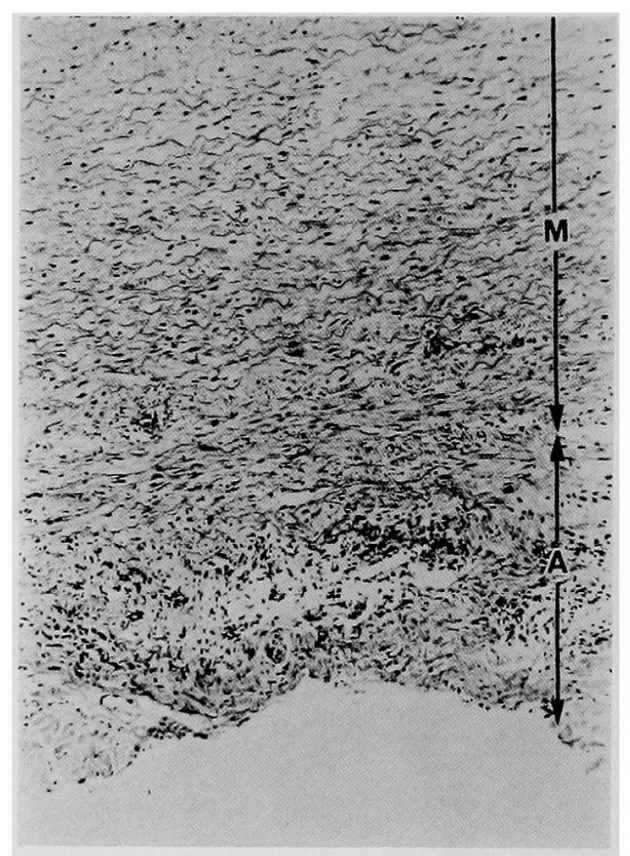

Fig. 4. Histological section of the ascending thoracic aorta. Mildly thickened adventitia (A) and outer side of the media (M), and infiltration of mononuclear cells. (Hematoxylin-eosin, $\times 120$ )

of the exercise, the heart rate and blood pressure increased to $146 / \mathrm{min}$ and $156 / 90 \mathrm{mmHg}$ respectively, without complications. The ST segment depression persisted for 9 min. Cardiac catheterization showed normal pressure and oxygen values. A selective coronary arteriogram revealed a greater than $90 \%$ occlusion at the ostium of left main coronary artery (Fig. 2). There was no stenosis or wall irregularity in the other coronary arteries. The left ventricular angiogram showed an ejection fraction of $70 \%$ with no abnormal wall motion. Thoracic aortography demonstrated stenotic lesions at the right carotid artery (Fig. 3). The remainder of the aorta and its branches were normal. A pulmonary perfusion scintigraphy, using I $^{131}$ labelled macroaggregates of albumin, revealed no reduction of the blood flow in the lung. The patient underwent aortocoronary bypass surgery. The aortic wall was found to be mildly thickened; the lumen of the coronary arteries appeared normal on inspection through arteriotomy. There was no obvious inflammation surrounding the great vessels of the heart. The wall of the ascending aorta was biopsied at operation for the microscopic examination. This specimen demonstrated a mildly thickened adventitia and outer side of the media. There were infiltrations of mononuclear cells, particularly lymphocytes, in the adventitia, the outer part of media and the vasa vasorum (Fig. 4). 
The diagnosis was established on the basis of clinical and pathological features. The postoperative course was uneventful. One month after operation, the treadmill exercise test showed no ST segment depression and chest pain was nil. The patient is under treatment with dipyridamole $(225 \mathrm{mg} /$ day) and aspirin (330 $\mathrm{mg} /$ day).

\section{Discussion}

Coronary arterial involvement in Takayasu's disease have been documented either angiographically or at necropsy since the report of Frovig and Lokens in 1951.20) The incidence was inferred to be $9-10 \%$ in Japan ${ }^{6)}$ or other countries. ${ }^{3)}$ Angiographic studies revealed lesions involving the coronary arteries in 14 cases (Table I). Included are 9 cases in Japan and 5 cases in other countries. All revealed subtotal ostial narrowing of either the right or the left coronary artery or both, and all had a history of angina pectoris. Angina pectoris in this disorder can be caused by aortic regurgitation, ${ }^{11}$ coronary ostial narrowing or the steal phenomenon with coronary-brachial arterial anastomosis. ${ }^{14)}$ In this case, however, aortic regurgitation was excluded by aortography and subtotal occlusion of the left coronary ostium was demon-

Table I. Glinical Features of 14 Patients with Takayasu's Disease Involving the Coronary Artery Diagnosed by Coronary Arteriography

\begin{tabular}{|c|c|c|c|c|c|c|}
\hline Case & Age & Sex & Reference & Angina & $\begin{array}{c}\text { Narrowed } \\
\text { Coronary Artery }\end{array}$ & $\begin{array}{l}\text { Clinical } \\
\text { Course }\end{array}$ \\
\hline 1 & 49 & $\mathbf{F}$ & Gotsman et $\mathrm{al}^{9)}$ & + & Ostium RGA & \\
\hline 2 & 18 & $\mathbf{F}$ & Young et al $^{10)}$ & + & Ostium LCA $95 \%$ & ACB \\
\hline 3 & 31 & $\mathbf{F}$ & Ree et $a^{11)}$ & + & $\begin{array}{lll}\text { Ostium } & \text { LCA } & 75 \% \\
\text { Ostium } & \text { RCA } & 50 \%\end{array}$ & ACB \\
\hline 4 & 33 & $\mathbf{F}$ & Huang et $\mathrm{al}^{12)}$ & + & Ostium LCA $95 \%$ & $\mathrm{ACB}$ \\
\hline 5 & 42 & F & Shimakura et al ${ }^{13)}$ & + & Ostium LCA $100 \%$ & \\
\hline 6 & 50 & $\mathrm{~F}$ & Shibuya et al ${ }^{14}$ ) & + & Ostium LCA & \\
\hline 7 & 38 & $\mathbf{F}$ & Shibuya et al ${ }^{14)}$ & + & Ostium LCA & \\
\hline 8 & 26 & $\mathrm{~F}$ & Cipriano et al $^{15)}$ & + & $\begin{array}{l}\text { Ostium LCA } 80 \% \\
\text { Ostium RCA } 80 \%\end{array}$ & ACB \\
\hline 9 & 37 & $\mathbf{M}$ & Kawahata et al $^{18)}$ & + & Ostium RCA $100 \%$ & \\
\hline 10 & 26 & $\mathrm{~F}$ & Wakiya et $a^{(17)}$ & + & Ostium LCA $99 \%$ & ACB \\
\hline 11 & 22 & $\mathbf{F}$ & Wakiya et al $^{17)}$ & + & Ostium LCA $99 \%$ & ACB \\
\hline 12 & 32 & $\mathbf{F}$ & Takizawa et $a^{18)}$ & + & Ostium LCA $90 \%$ & ACB \\
\hline 13 & 45 & $\mathbf{F}$ & Chun et al ${ }^{19)}$ & + & Ostium LCA $95 \%$ & \\
\hline 14 & 23 & $\mathbf{F}$ & Makino et al & + & Ostium LCA $90 \%$ & $\mathrm{ACB}$ \\
\hline
\end{tabular}

Abbreviations : $\mathbf{R C A}=$ right coronary artery ; LCA =left coronary artery; $\mathbf{A C B}=$ aortocoronary bypass graft operation. 
strated by coronary angiography as the etiology for angina pectoris. Coronary-brachial anastomosis was not observed.

The ST segment depression in women during exercise testing has been described as a less specific indicator of coronary artery disease, ${ }^{21)}$ especially in asymptomatic women. ${ }^{22)}$ However, the exercise stress test in our patient brought about the typical chest pain of angina pectoris, with a maximum ST segment depression of $0.4 \mathrm{mV}$ that persisted for $9 \mathrm{~min}$. ST segment depression over $0.4 \mathrm{mV}$ is assumed to be associated with left main or multivessel disease, especially if change occurs in Bruce stage 1 or 2.23) Moreover, the persistance of ST depression $8 \mathrm{~min}$ into recovery suggests the likelihood of stenosis in the left main coronary artery. ${ }^{24)}$

There is some evidence suggesting that large doses of corticosteroids may halt or even reverse the lesions during the active inflammatory phase of Takayasu's disease. ${ }^{1,25)}$ However, during the chronic phase of the disease as in our patient, fibrosis and thrombus formation were responsible for the lesions and resulting symptoms and the administration of steroids would probably not have been effective. Since the left main coronary artery stenosis places a large amount of the muscle in jeopady and may lead to myocardial infarction or even sudden death, the coronary arterial bypass graft operation is mandatory for patients with a coronary narrowing due to Takayasu's disease. The fact that the coronary arterial stenosis in Takayasu's disease tends to be confined characteristically to the ostium ${ }^{8)-19)}$ and proximal segments of coronary arteries favours consideration of the bypass graft operation.

We recommend that the treadmill exercise test be used to detect suspected coronary arterial involvement in patients with Takayasu's disease. In addition, selective coronary angiography should be performed in patients with a positive exercise test and symptoms of chest pain. If the coronary angiogram reveals a coronary ostial stenosis of a severe grade, an aortocoronary bypass graft operation should be performed as soon as possible in selected cases with no or mild inflammatory process for the treatment of this potentially lethal disorder.

\section{ACKnOWLedgment}

We thank M. Ohara for comments on the manuscript.

\section{REFERENGES}

1. Ueda $\mathbf{H}$ : Clinical and pathological studies of aortitis syndrome. Committee report. Jpn Heart J 9 : 76, 1968

2. Saito Y, Hirota K, Ito I, Yamaguchi H, Takeda T, Morooka S, Ueda H: Clinical and patho- 
logical studies of five autopsied cases of aortitis syndrome. Part 1. Jpn Heart J 13: 107, 1972

3. Lupi-Herrera E, Sanchez-Torres G, Marcushamer J, Mispireta J, Horwitz S, Vela JE: Takayasu's arteritis. Clinical study of 107 cases. Am Heart J 93: 94, 1977

4. Domingo RT, Maramba TP, Torres LF, Westolowski SA: Acquired aorto-arteritis. Arch Surg 95: 780, 1967

5. Lande A, Bard R, Rossi P, Passariello R, Castrucci A: Takayasu's arteritis. NY State Med 74: 1477,1976

6. Nasu T: Autopsy study of aortitis syndrome. Report by the Ministry of Health and Welfare, Japan, p 111, 1975 (in Japanese)

7. Cheitlin MD, Carter PB: Takayasu's disease. Arch Intern Med 116: 283, 1965

8. Inokuchi $\mathrm{K}$, Yagi $\mathrm{H}$, Nakamura $\mathbf{M}$, Torii S: A case of pulseless disease developing angina pectoris. Kokyu to Junkan 9: 447, 1961 (in Japanese)

9. Gotsman MS, Beck V, Schrire V: Selective angiography in arteritis of the aorta and its branches. Radiology $88: 232,1967$

10. Young JA, Sengupta A, Khaja FU: Coronary ostial stenosis, angina pectoris and typical coarctation of the aorta due to nonspecific arteritis. Treatment with aortocoronary bypass graft. Am J Cardiol 32: 356, 1973

11. Ree Y, Koyama M, Ishikawa S, Hanzawa S, Onosato Y, Karaushi Y: Aortocoronary bypass graft for coronary narrowing. Heart 5: 246, 1973 (in Japanese)

12. Huang PJ, Chu SH, Chen CM: Takayasu's arteritis with coronary occlusion and periinfarction angina. Formosan Med Assoc 74: 469, 1975

13. Shimakura $T$, Endo $M$, Konno S: Coronary angiogram in aortitis syndrome. Heart 7: 1517,1975 (in Japanese)

14. Shibuya $T$, Tsubokura $T$ : Cardiovascular angiogram in aortitis syndrome: Committee report by clinical and pathological studies of aortitis syndrome by the Ministry of Health and Welfare, Japan, p 44-49, 1964 (in Japanese)

15. Gipriano PR, Silverman JF, Perlroth MG, Griepp RB, Wexler L: Coronary arterial narrowing in Takayasu's aortitis. Am J Cardiol 39: 744, 1977

16. Kawahata A, Kato Y, Goto T, Kamishima J, Yahata Y, Kadohari Y, Muramatsu J, Kikawada $R$ : A case of aortitis syndrome with right coronary ostial complete obstruction (abstr). J Jap Soci Int Med 67: 640, 1979 (in Japanese)

17. Wakiya Y, Murayama K, Sakurai H, Iemoto T, Kanoh T, Abe H, Okada R, Kitamura K, Amano J, Suzuki A : A case of aortitis syndrome with left coronary ostial stenosis. Heart 11 : 435, 1979 (in Japanese)

18. Takizawa A, Mukaino K, Sasaki Y, Fujino M, Naito S, Arakawa K, Onimura S, Asao M: A case of aortitis syndrome with left coronary ostial stenosis (abstr). J Jap Soci Int Med 70: 449, 1980 (in Japanese)

19. Chun MPKC, Jones GR, Davia JE, Lawrence PJ: Coronary ostial stenosis in Takayasu's arteritis. Chest 78: 330, 1980

20. Frovig AG, Lokens AC: Syndrome of obliteration of the arterial branches of the aortic arch due to arteritis. Acta psych Neur Scand 26: 313, 1951

21. Cumming GR, Dufresne C, Kick L, Samm J: Exercise electrocardiogram patients in normal woman. Brit Heart J 35: 1055, 1973

22. Kusumi F, Bruce RA, Ross MA, Trimbe S, Voigt AE: Elevated atrial pressure and postexertional ST segment depression in middle-age woman. Am Heart J 92: 576, 1976

23. Goldman S, Tselos S, Chohn K: Marked depth of ST segment depression during exercise testing. Indicator of severe coronary artery disease. Chest 69: 729, 1976

24. Goldschlager N, Selzer A, Cohn K: Treadmill stress as indicator of presence and severity of coronary artery disease. Ann Intern Med 85: 277, 1976

25. Bonventre MV: Takayasu's disease. Revisited. NY State J Med 74: 1960, 1974 